\title{
https://doi.org/10.46813/2020-130-107 \\ AN ATTEMPT FOR INCREASING THE EFFICIENCY OF PENNING SOURCE OF H' IONS WITH A METAL HYDRIDE CATHODE
}

\author{
I. Sereda, D. Ryabchikov, Ya. Hrechko, Ie. Babenko \\ V.N. Karazin Kharkiv National University, Kharkiv, Ukraine \\ E-mail: igorsereda@karazin.ua
}

The possibility of increasing the current of negative hydrogen ions extracted in the longitudinal direction from a Penning discharge with a metal hydride cathode by reducing the anode-cathode distance is shown. The features of $\mathrm{H}^{-}$ions emission have been revealed depending on the electric shift on the metal hydride cathode and the external magnetic field. The power parameters of the electromagnetic filter have been optimized for the separation of negative ions from the extracted flux of charged particles. The current of $\mathrm{H}^{-}$ion beam was obtained at the level of $16 \mu \mathrm{A}$ with hydrogen supply only from the metal hydride cathode and at the level of $0.1 \mathrm{~mA}$ at external supply from the balloon.

PACS: $52.80 . \mathrm{Sm}$

\section{INTRODUCTION}

Developing the resonance theory of dissociative attachment to hydrogen molecules designates a compound state formed by the interaction of an incident electron with a target excited molecule $\mathrm{H}_{2}{ }^{*}$ in which the incident electron is temporarily captured in the neighborhood of the molecule. The decay of this compound state can lead to dissociative attachment with formation of $\mathrm{H}^{-}$ion and a neutral atom $\mathrm{H}$ [1]. The excitation of molecules can be carried out efficiently by high-energy electron or by using special materials metal hydrides that can store hydrogen and release it in an already excited state [2]. It sufficiently increases $\mathrm{H}^{-}$ ion formation due to the energy saving that would be spent on the excitation of a $\mathrm{H}_{2}$ molecule in plasma.

It is no matter how small the cross sections of negative ion formation, because due to the increasing of molecules density, molecular ions and electrons, one can ensure an arbitrarily high rate of $\mathrm{H}^{-}$ions generation in plasma. The limiting factor of intense $\mathrm{H}^{-}$ions flow formation is the collisional destruction of negative ions with positive ions, electrons and hydrogen atoms. Therefore, the efficient sources with volume generation should operate at low pressure (less than $10^{-4}$ Torr) and low plasma density $\left(n<10^{11} \mathrm{~cm}^{-3}\right)$ [3]. These requirements are met, for instance, in Penning discharge, which is a main type of internal ion source for cyclotron. It is usually provides an extracted beam current of tens $\mu \mathrm{A}$ under the pressure of $10^{-5}$ Torr.

Because of a large number of slow electrons by a cathode [4], there is a preferable place of $\mathrm{H}^{-}$ions formation due to electron dissociative attachment to excited molecules $\mathrm{H}_{2}{ }^{*}$. If a cathode is made of metal hydride, the $\mathrm{H}_{2}{ }^{*}$ molecules are formed due to the activation of desorbed hydrogen directly by its surface [5] and the yield of negatively charged particles including negative ions and electrons is performed along the external magnetic field $[6,7]$.

In our previous work we obtained the $\mathrm{H}^{-}$ion current of $10 \mu \mathrm{A}$ at an input power of $6 \mathrm{~W}$ from Penning type ion source with metal-hydride cathode [8]. Maximum extracted current was observed at electrical bias of metal-hydride cathode. The purpose of this article is to investigate the possibility of increasing the current of negative hydrogen ions by changing the distance between the electrodes together with potentials at the discharge electrodes.

\section{EXPERIMENTAL SETUP}

Hydrogen plasma was formed inside a tubular anode (2), made from stainless steel and between a metal hydride cathode (1) and a copper cathode-reflector (3) (Fig. 1). Against our previous works [7, 8] the distance between anode and cathodes was reduced to $0.3 \mathrm{~cm}$. The discharge operation was ensured by applying a positive potential $U_{a}$ to the anode. On the cathodes there was a possibility of supplying an electric bias. Behind the central aperture in the cathode-reflector (5) an electromagnetic filter was set. It consists of a grid (7) for positive ions reflecting, a magnetic coil (9) for electrons diverting, a collector of diverted electrons (8) and a collector of extracted axial beam of $\mathrm{H}^{-}$ions (10).

The metal hydride cathode (1) was produced from hydride-forming alloy $Z r_{50} V_{50}$. The quantity of hydrogen stored in the cathode is $\sim 900 \mathrm{~cm}^{3}$ under normal atmospheric conditions. These compositions are characterized by high pumping rates and hydrogen storage capacity, they have low activation temperatures and easily desorb hydrogen when heated to moderately elevated temperatures.

For pressure being stabilized, the metal hydride cathode had got a water-cool and its temperature did not exceed $20{ }^{\circ} \mathrm{C}$, that much lower than the temperature of thermal destruction of hydride phases [2]. Therefore, $\mathrm{H}_{2}{ }^{*}$ desorption was determined only by a discharge current and is provided mainly by ion-stimulated processes from the surface of metal hydride [7].

\section{RESULTS AND DISCUSSION}

The reduction of the distance between an anode and cathodes to $0.3 \mathrm{~cm}$ causes no considerable changes in the discharge operation. As before, there are 3 discharge operation modes depending on the anode voltage $U_{a}$, and as before, only in the third mode at large $U_{a}$ there is a pronounced axial flow of negative particles. 


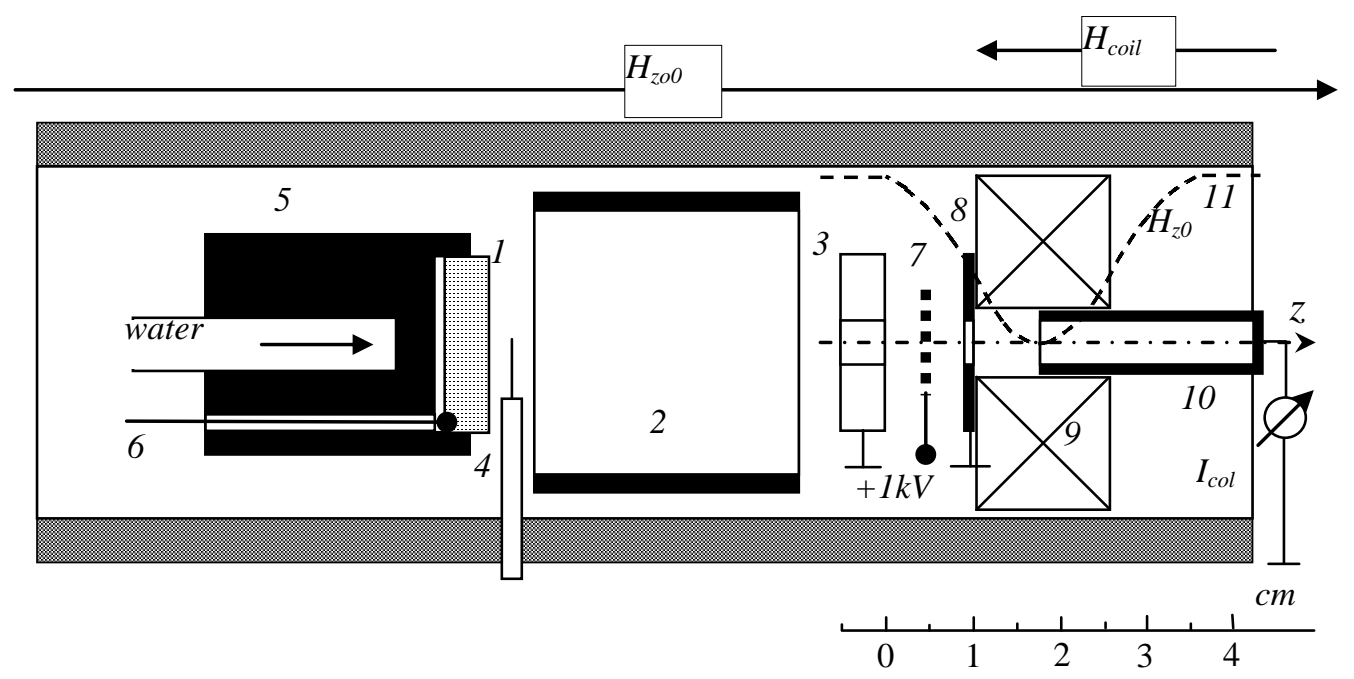

Fig. 1. The scheme of discharge cell:

1 - metal hydride cathode; 2 -anode; 3 - copper cathode-reflector; 4 -Langmuir probe; 5 -cathode-holder;

6 - thermocouple; 7 - retarding grid; 8 - electrons collector; 9 - coil of magnetic field; 10 - $H^{-}$ion collector; 11 - distribution of the magnetic field $H_{z 0}$ in the filter

But a decrease in the interelectrode distance, however, led to one unexpected effect: the total amount of $\mathrm{H}_{2}{ }^{+}$ions in the outgoing axial flow significantly decreased, so even at low $U_{a}$ after the discharge ignition the negative current of electrons and $\mathrm{H}^{-}$ions is registered on the collector.

The reason for this behavior, apparently, is the distortion of the anode layer by the cathodes, as well as a change in the geometry of the discharge gap, namely, a decrease in the solid angle at which the anode is visible from the collector. Thus, only $\mathrm{H}_{2}{ }^{+}$ions that move to the cathode along the axis of the discharge cell can fall on the collector. For reduction of the probability of electrical breakdown, the retarding grid potential was reduced to $1 \mathrm{kV}$.

There may be an opinion that the use of a retarding grid (7) under positive potential is not necessary. However, in addition to the retarding function for positive ions, it accelerates negative particles. Thus, electrons and $\mathrm{H}^{-}$ions are accelerated to approximately the same energy and can be successfully separated by the magnetic field $H_{z 0}$ of the filter. It demonstrates Fig. 2. At the increase in $H_{\text {coil }}$ the electrons retard to electron collector (8).

Calculations performed according to the procedure described in [7] show that the optimal magnetic field distribution in the filter $\left(H_{z 0}\right)$ corresponds to $H_{\text {coil }} / H_{z o O}=1$, but the experiments show that it could be expanded from 0.6 to 1 approximately. As it was shown in [8] negative electric bias on metal hydride cathode can enhance the yield of $\mathrm{H}^{-}$ions. But the reduction of inter electrode distance causes significant change in the behavior of negative ions current at negative shift on metal hydride cathode (Fig. 3). The curve inflection for $\mathrm{H}^{-}$ion current against the one reported previously [8] is observed only at elevated magnetic fields ( 0.08 and $0.1 \mathrm{~T}$ ) and is already not so pronounced. But at higher values of the electric bias $-U_{M H}$ the current does not fall, as it was in previous case, but on the contrary it grows.

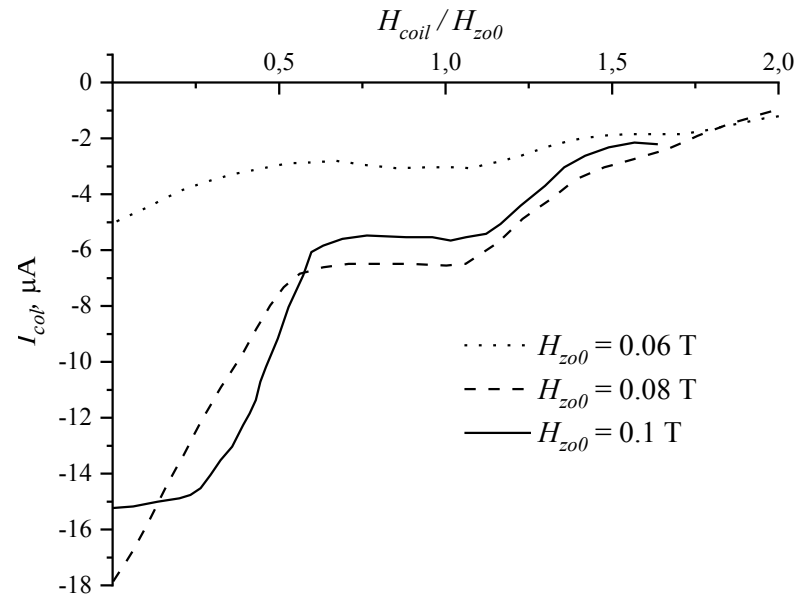

Fig. 2. The current of negative particles depending on magnetic field distribution in the filter at

$$
P=5 \cdot 10^{-6} \text { Torr, } U_{a}=5 \mathrm{kV}
$$

A decline in the $\mathrm{H}^{-}$current was explained by electrons depletion in the cathode region due to reflecting by $-U_{M H}$ reducing the rate of the dissociative electron attachment [8]. Secondary ion-electron emission from the surface of metal hydride cathode slows down the depletion of electrons and become a main source of slow electron in the cathode region, rather than reflected electrons from plasma.

The inflection point in the curve corresponds to plasma electron temperature $T_{e}$. So, another explanation of such $\mathrm{H}^{-}$current behavior could be a large $T_{e}$ or the existence of electrons groups with different $T_{e}$.

Unfortunately, at this stage we were not able to lower the potential of metal hydride cathode $U_{M H}$ below than $-100 \mathrm{~V}$ due to micro breakdowns. So, the maximum obtained current of $\mathrm{H}^{-}$ions has got a value of $15 \mu \mathrm{A}$.

Another standard possibility of raising the current of $\mathrm{H}^{-}$ions from a volume negative ions source is an increase of working pressure in the discharge cell. 


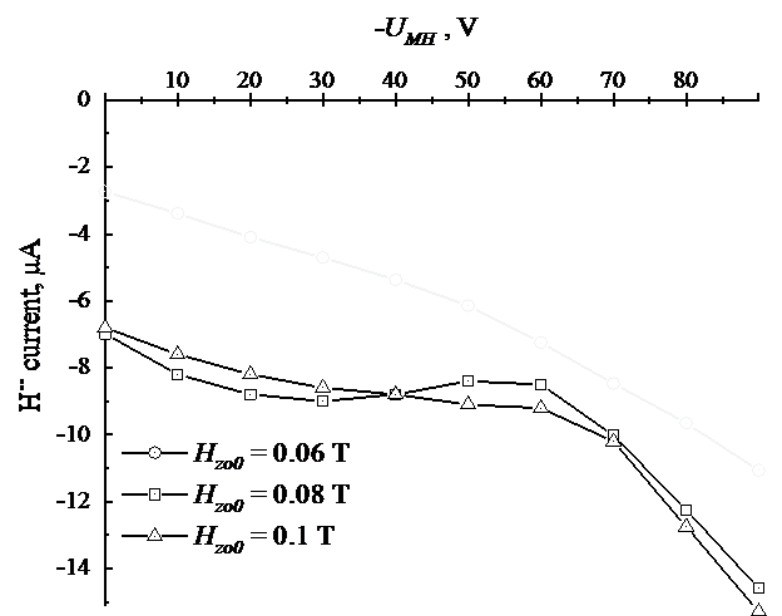

Fig. 3. $H^{-}$ion current depending on negative electric bias on metal hydride cathode at $U_{a}=5 \mathrm{kV}$,

$$
P=5 \cdot 10^{-6} \text { Torr }
$$

For this, in addition to locally injected hydrogen from metal hydride cathode, external balloon hydrogen supply into the vacuum chamber was also provided. There were no considerable changes in the operation of the discharge, and the behavior of volt-ampere characteristics were the same as in [8]. But only the discharge current $I_{d}$ doubled and reached the value of $3 \mathrm{~mA}$ at $U_{a}=5 \mathrm{kV}$.

Fig. 4 shows the plasma parameters measured on the axis by metal hydride cathode. Plasma density and electron temperature $T_{e}$ also takes on increased values when the pressure raises. Electric bias on metal hydride cathode $-U_{M H}$ impacts the density and plasma electron temperature. One can see they behave differently depending on the way of the realization of hydrogen injection into the discharge cell.

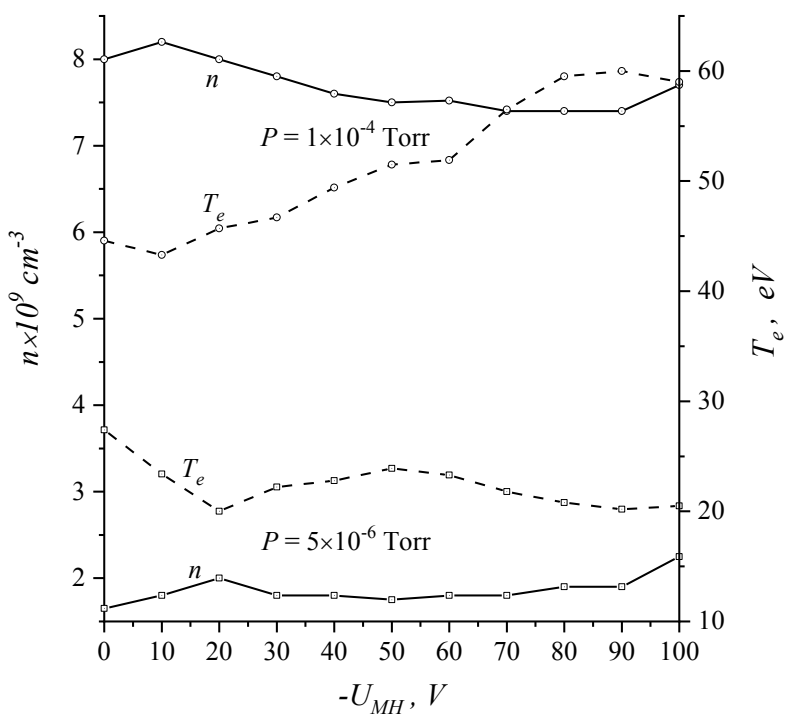

Fig. 4. Plasma density and temperature on the axis by metal hydride cathode at $H_{z o 0}=0.1$ Torr and $U_{a}=5 \mathrm{kV}$

An increase of pressure to $1 \cdot 10^{-4}$ Torr leads to the growth of $\mathrm{H}^{-}$ions current by an order of magnitude (Fig. 5). The maximum current of negative ions of $0.1 \mathrm{~mA}$ was obtained in this case. Of course, it is no longer a gas-feed-free source, we just show a way of further source improvement.

At further increase of pressure, the discharge transforms into a high-current form with a current of $50 \mathrm{~mA}$ and a voltage drop of $1.2 \mathrm{kV}$. Moreover, maintaining this mode is possible even when the external hydrogen supply is turned off and hydrogen is desorbed only from metal hydride cathode. Unfortunately, we did not register the yield of negative particles in the longitudinal direction in this case. Perhaps, the transverse extraction method will be more suitable here.

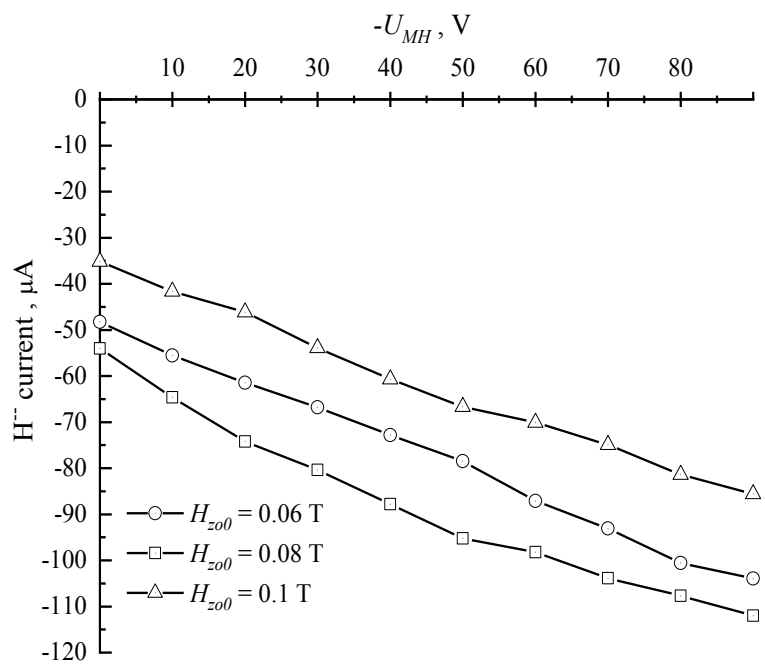

Fig. 5. $H$ ion current depending on negative electric bias on metal hydride cathode at $U_{a}=5 \mathrm{kV}$, $P=1 \cdot 10^{-4}$ Torr

Fig. 6 shows the dependence of the $\mathrm{H}^{-}$ion current on the anode voltage for different bias values at the metal hydride cathode. A clear tendency of increasing the $\mathrm{H}^{-}$ current with $U_{a}$ indicates on the possibility of further development and improvement of this type of source.

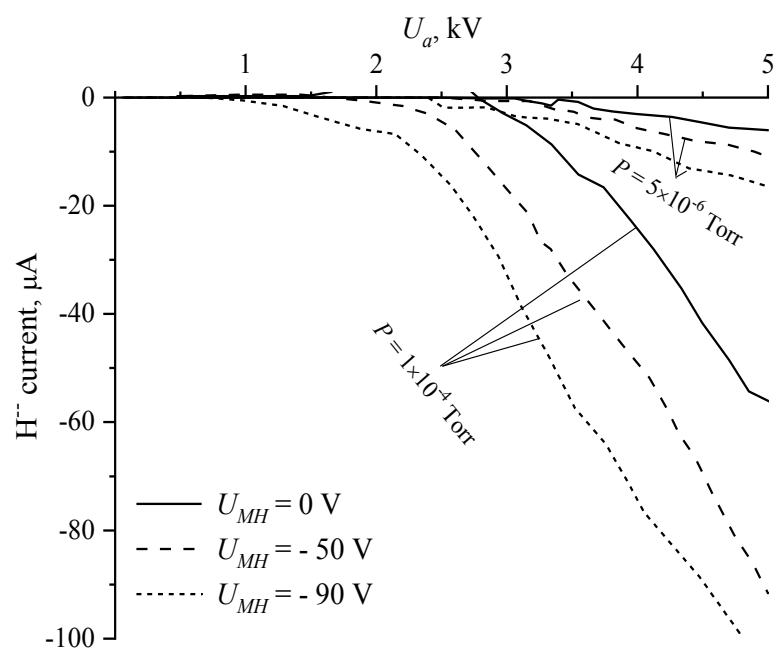

Fig. 6. $H$ ion current depending on anode voltage $U_{a}$ at $H_{z o 0}=0.1 T$

In the observed Penning source with metal hydride cathode activated hydrogen is supplied by desorption from metal hydride due to the cathode surface bombardment by charged particles from plasma. 
Thus, the main task for implementing the concept of a gas-feed-free source is an increase in pressure that must be realized due to an increase in the discharge current and, accordingly, the particle current to metal hydride cathode.

\section{CONCLUSIONS}

Hydrogen desorption from metal hydride cathode, caused by the ion bombardment of the surface, leads to a significant increase in the yield of negative ions in comparison with external balloon hydrogen supply. $\mathrm{H}^{-}$ ions could be simply extracted in longitudinal direction due to the application of metal hydride in Penning discharge, which operates at low pressure.

For increasing the $\mathrm{H}^{-}$current one should supply a negative potential on metal hydride cathode. The obtained current of negative hydrogen ions could be increased by raising the level of the power introduced into the discharge, by optimization of the geometry and by the choice of metal hydride cathode.

Such type a gas-feed-free source is of interest for extremely high-vacuum devices continuous-type beams to inject.

\section{REFERENCES}

1. J.R. Hiskes. Cross sections for the vibrational excitation of the $\mathrm{H}_{2}\left(\mathrm{X}_{1}{ }^{{ }^{+}} \mathrm{g}\right)$ state via electron collisional excitation of the higher singlet states // J. Appl. Phys. 1980, v. 51, № 9, p. 4592-4594.
2. G. Sandrock. Hydrogen energy system. Production and utilization of hydrogen and future aspects // Nato Science Series E 295 / Ed. Yurum, Y. Norwell: «Kluwer Academic Publishers», 1995, p. 135.

3. M. Bacal, R. McAdams, B. Lepetit. The negative ion mean free path and its possible implications // Second International Symposium on Negative Ions, Beams and Sources, AIP Conf. Proc. 2011, v. 1390, p. 13.

4. O.J. Orient, A. Chutjian, S.H. Alajazian. Reversal ion source: A new source of negative ion beams // Rev. Sci. Instrum. 1985, v. 56, № 1, p. 69-72.

5. I.V. Borgun, D.L. Ryabchikov, I.N. Sereda, A.F. Tseluyko. PIG charged particle source with hydrogen supply from a metal-hydride cathode // $J$. Phys. Conf. Ser. 2014, v. 514, p. 012051.

6. I. Sereda, A. Tseluyko, N. Azarenkov. The Application of Metal Hydride Based on Zr-V Alloy in Hydrogen Plasma // Hydrides: Types, Bonds and Applications / Ed. Patrick C. Dam. New York: «Nova Science Publishers Inc», 2018, p. 149-192.
7. I. Sereda,
A. Tseluyko,
N. Azarenkov,

D. Ryabchikov, Ya. Hrechko. Effect of metal-hydride hydrogen activation on longitudinal yield of negative ions from PIG // International Journal of Hydrogen Energy. 2017, v. 42/34, p. 21866-21870.

8. I.N. Sereda, Ya.O. Hrechko, D.L. Ryabchikov, A.F. Tseluyko, N.A. Azarenkov. The increasing of Hcurrent from Penning ion source with electrically biased metal hydride cathode // Vacuum. 2019, v. 162, p. 163167.

Article received 28.09 .2020

\title{
ПОПЫТКА УЛУЧШЕНИЯ ЭФФЕКТИВНОСТИ РАБОТЫ ПЕННИНГОВСКОГО ИСТОЧНИКА ИОНОВ Н С МЕТАЛЛОГИДРИДНЫМ КАТОДОМ
}

\author{
И. Середа, Д. Рябчиков, Я. Гречко, Е. Бабенко
}

Показана возможность увеличения тока отрицательных ионов водорода, извлекаемых в продольном направлении из разряда Пеннинга с металлогидридным катодом путем уменьшения анод-катодного расстояния. Выявлены особенности эмиссии ионов $\mathrm{H}^{-}$в зависимости от электрического смещения металлогидридного катода и внешнего магнитного поля. Оптимизированы параметры питания электромагнитного фильтра для сепарации отрицательных ионов из извлекаемого потока заряженных частиц. Получен ток пучка ионов $\mathrm{H}^{-}$на уровне 16 мкА при напуске водорода только из металлогидридного катода и на уровне 0,1 мА в условиях дополнительного внешнего напуска из баллона.

\section{СПРОБА ПОЛІШЕННЯ ЕФЕКТИВНОСТІ РОБОТИ ПЕННІНГОВСЬКОГО ДЖЕРЕЛА ІОНІВ Н 3 МЕТАЛОГІДРИДНИМ КАТОДОМ}

\section{I. Середа, Д. Рябчиков, Я. Гречко, С. Бабенко}

Показана можливість збільшення струму негативних іонів водню, що виходять у поздовжньому напрямку 3 розряду Пеннінгу з металогідридним катодом шляхом зменшення анод-катодної відстанні. Виявлено особливості емісії іонів $\mathrm{H}^{-}$у залежності від електричного зміщення металогідридного катоду і зовнішнього магнітного полю. Оптимізовано параметри живлення електромагнітного фільтра для сепарації негативних іонів з потоку заряджених частинок, що витягується. Отримано струм пучка іонів $\mathrm{H}^{-}$на рівні 16 мкА при напуску водню тільки 3 металогідридного катоду і на рівні 0,1 мА в умовах додаткового зовнішнього напуску з балону. 